\title{
FETUIN A AS AN EARLY MARKER OF DIABETIC NEPHROPATHY IN PATIENTS WITH TYPE 2 DIABETES MELLITUS
}

\author{
By \\ Noura A. Mitkees, Hoda M. El-Sayed, Adela M. Gad, Hayam H. \\ Mansour, Nagwa A. Mohamed* \\ Departments of Internal Medicine and clinical pathology*, Al-Azhar Faculty of medicine \\ and National Research Center* \\ Corresponding author: Noura Abd El-Aziz Mitkees, Mobile: 01555528880, \\ E-mail: nouramitkees@yahoo.com
}

\begin{abstract}
Background: Fetuin-A is a liver-derived plasma protein, mediates the formation and stabilization of calciprotein particles formation, ensures mineral solubilization, thus preventing pathological calcification, also it promotes insulin resistance.

Objective: To study the role of fetuin A as a marker for early diabetic nephropathy in type 2 diabetes mellitus.

Subjects and Methods: Cross sectional study including 30 diabetic patients without microalbuminuria (group I), 30 diabetic patients with microalbuminuria (Group II) and age and sex matched 30 healthy subjects served as a control group. All patients and control subjects were thoroughly examined clinically. Fasting and post prandial blood sugar, $\mathrm{HbA1c}$, renal function tests, lipid profile, creatinine clearance, albumin/creatinine ratio and serum fetuin A by ELISA were investigated.
\end{abstract}

Results: Serum Fetuin A increased in diabetic nephropathy patients without microabuminuria compared to those with microabuminuria. Significant negative correlation was found between serum Fetuin A and albumin/creatinine ratio in diabetic patients with and without microalbuminuria. Cut off value of serum fetuin A was >294.2 ug/dl with sensitivity of $93.3 \%$,specificity $93 \%$, positive predictive value $92.7 \%$, negative predictive value $93.8 \%$ and diagnostic accuracy $91.6 \%$.

Conclusion: Serum fetuin A can be used as an early marker for diabetic nephropathy before development of microalbuminuria in patients with type 2 diabetes mellitus.

Keywords: Diabetes Mellitus, Microalbuminuria, Serum Fetuin A, Diabetic nephropathy

\section{INTRODUCTION}

Diabetic complications associated with hyperglycemia impair the metabolism of carbohydrates, fats, proteins and electrolytes, all of which can disrupt the vascular system. Many endothelial capillary cells are damaged under these conditions, including those in the retina, renal glomerulus, and both central and peripheral nerves due to excessive harmful accumulation of glucose in these cells (Forbes and Coope., 2013).

Diabetic kidney disease is usually a clinical diagnosis made based on the presence of albuminuria and/or reduced estimated glomerular filtration rate (eGFR) in the absence of signs or symptoms of other causes of kidney 
damage. The typical presentation of diabetic kidney disease is considered to include a long-standing duration of diabetes, retinopathy, albuminuria without hematuria, and gradually progressive loss of eGFR (Afkarian et al., 2016).

Microalbuminuria (MA); is the result of increased vascular permeability which develops as a renal manifestation of generalized vascular endothelial injury, that may make it a valuable early predictor of atherosclerosis and cardiovascular mortality, So the early identification and treatment of patients at increased risk for microalbuminurea may be important to limit the excess renal and cardiovascular disease associated with type 2 diabetes (Hasan et al., 2015).

Fetuin-A acts as a natural inhibitor of the insulin receptor tyrosine kinase in liver and skeletal muscle. Fetuin A was found to improve insulin sensitivity. Different observational studies have proposed that high serum fetuin-A levels are associated with the presence or development of the metabolic syndrome suggesting fetuin-A as a risk factor for this condition (Dutta et al., 2014).

Good evidence suggests that early treatment delays or prevents the onset of diabetic nephropathy or diabetic kidney disease. This has consistently been shown in both type 1 and type 2 diabetes mellitus (Bjornstad et al., 2014). Therefore diagnostic and prognostic markers to predict diabetic nephropathies at early stages are important as early intervention can slow down deterioration of kidney function and improve patient outcomes (Persson and Rossing, 2018). Although diabetic nephropathy has been tradition $\neg$ ally diagnosed on the basis of measurement of urinary albumin or eGFR, investigators are searching for alternative or additional measurements for predicting the development and progression of diabetic nephropathy. So, studies are needed to measure key proteins in serum or urine of diabetic patients that seem to be linked to various pathological processes involved in the susceptibility to and progression of diabetic nephropathy (Calcutt et al., 2009).

The aim of the present study was to investigate the role of serum fetuin $\mathrm{A}$ in early detection of diabetic nephropathy in type 2 diabetic patients.

\section{PATIENTS AND METHODS}

This was a cross sectional study including sixty patients with type 2 diabetes mellitus and thirty healty control. All patients and control were selected from Al-Zhraa University Hospital, AlAzhar University during the period between May 2017 and December 2017.

Approval of the ethical committee and written informed consents from all participants were obtained.

\section{Inclusion criteria:}

All patients known to have type 2 diabetes mellitus age ranging from $30-$ 60 years old.

\section{Exclusion criteria:}

All patients known to have history of cardiovascular disease, stroke or transient ischemic attacks, liver disease, evidence of sepsis, inflammatory bowel disease, and obstructive lung disease were excluded from the study. Individuals with risk factor of diabetes mellitus as obesity, family history of DM, impaired fasting 
glucose level were also excluded from control group.

\section{Subjects were classified as follows:}

Group I: Thirty healthy age and sex matched subjects were studied for control.

Group II: including thirty patients with type 2 diabetes mellitus without microalbuminuria.

Group III: Included thirty patients with type 2 diabetes mellitus with microalbuminuria.

After thorough clinical examination, the following laboratory investigations were done: full blood count, liver function tests, fasting blood glucose, two hours postprandial blood glucose, glycosylated hemoglobin (HbA1c), total cholesterol, triglycerides, HDL, LDL, urine analysis, blood urea, serum creatinine, microalbuminurea by albumin /creatinine ratio, 24 hour urine collection for creatinine clearance and determination of serum fetuin-A level which was carried out by using quantitative sandwich enzyme linked immunoassay analysis (ELISA) technique X-ray chest and echocardiography were investigated for each subject.

\section{Statistical analysis:}

Data entry, processing and statistical analysis was carried out using MedCalc ver. 18.2.1 (MedCalc, Ostend, Belgium). Tests of significance (Kruskal wallis and Mann-Whitney's, Spearman's correlation, and ROC Curve analysis) were used. Pvalues less than $0.05(5 \%)$ was considered to be statistically significant. wher Pvalue $>0.05$.

\section{RESULTS}

Ninety subjects have participated in this study and were classified as: Group I Thirty healthy control subjects. They were seven males $(23.33 \%), 23$ females (76.67\%), their ages ranged from 32 to 60 years with mean $( \pm$ SD) 44.1( $( \pm 8.43)$. Group II thirty diabetic patients without microalbuminuria; were nine males $(30 \%)$ and 21 females $(70 \%)$, their ages ranged from 31 to 60 years with mean $( \pm$ SD) $50.33( \pm 9.49)$ years and group III thirty diabetic patients with microalbuminuria were four males $(13.33 \%)$ and 26 females (86.67\%), their ages ranged from 41 to 64 years with mean $( \pm$ SD) $50.37( \pm 6.82)$ years. There was a highly significant increase in disease duration in group III diabetic patients with microalbuminuria compared to group II diabetic patients without microalbuminuria with mean $( \pm$ SD) $12.43( \pm 3.02)$ years Vs. $6.58( \pm 2.7)$ years respectively, and $\mathrm{P}$ value was $<0.01$ (Table 1). 
Table (1): Age ,sex and duration of sixty diabetic patients with type 2 diabetes and thirty healthy control

\begin{tabular}{|c|c|c|c|c|c|}
\hline & Groups & Group I & Group II & Group III & \multirow{2}{*}{ P-vahue } \\
\hline \multicolumn{2}{|c|}{ Parameters } & (Control) & (Diabetics without MA*) & (Diabetics with MA) & \\
\hline \multicolumn{2}{|c|}{ Age / Years (mean \pm SD) } & $44.1 \pm 8.43$ & $50.33 \pm 9.49$ & $50.37 \pm 6.82$ & $<0.01$ \\
\hline \multirow[t]{2}{*}{ Sex } & Male $\%$ & $7(23.33 \%)$ & $9(30 \%)$ & $4(13.33 \%)$ & \multirow{2}{*}{$>0.05$} \\
\hline & Female $\%$ & $23(76.67 \%)$ & $21(70 \%)$ & $26(86.67 \%)$ & \\
\hline \multicolumn{2}{|c|}{ Duration of diabetes / } & & \multirow{2}{*}{$6.58 \pm 2.7$} & \multirow{2}{*}{$12.43 \pm 3.02$} & \multirow{2}{*}{$<0.001$} \\
\hline \multicolumn{2}{|c|}{ Years (mean $\pm \mathrm{SD}$ ) } & - & & & \\
\hline
\end{tabular}

There was a highly significant increase in mean $( \pm \mathrm{SD})$ of albumin/creatinine ratio in group III diabetic patients with microalbuminuria $(205.3 \pm 93.7 \mathrm{mg} / \mathrm{mmol})$ compared to group II diabetic patients without microalbuminuria $(14.47 \pm 5.10)$ $\mathrm{mg} / \mathrm{mmol}$ ) and group I healthy control $(13.27 \pm 93.7 \mathrm{mg} / \mathrm{mmol})$ and $\mathrm{p}$ value $<0.01$. Also, there was a significant increase in serum fetuin A in group I healthy control $(289.78 \pm 2.92 \mathrm{ug} / \mathrm{dl})$, group II diabetic patients without microalbuminuria $(412.91 \pm 39.78 \mathrm{ug} / \mathrm{dl})$ compared to group III diabetic patients with microalbuminuria $(240.27 \pm 27.38 \mathrm{ug} / \mathrm{dl})$ and $\mathrm{p}$ value was $<0.01$.

There was a highly statistical significant difference between Group I healthy control, Group II diabetic patients without microalbuminuria and group III diabetic patients with microalbuminuria in fasting blood sugar which were $92.73 \pm 4.4$, $205.5 \pm 92.8,198.3 \pm 80.5 \mathrm{mg} / \mathrm{dl}$ respectively and p-value was <0.01. Two hours postprandial blood sugar which were $114.9 \pm 7.66, \quad 256.9 \pm 109.8, \quad$ and $262.2 \pm 86 \mathrm{mg} / \mathrm{dl}$ respectively and P-value was $<0.01$. HbA1C which were $5.023 \pm$ $0.39,9.46 \pm 1.09$ and $9.77 \pm 0.966 \%$ respectively and $\mathrm{P}$-value was $<0.01$. Total cholesterol which were $78.54 \pm 25.11$, $218.09 \pm 18.84$ and $204.41 \pm 24.17 \mathrm{mg} / \mathrm{dl}$ respectively and P-value was $<0.01$ (Table 2).

There was no significant difference in blood urea, serum creatinine, creatinine Clearance, triglycerides, LDL, HDL and serum calcium between the three groups (Table 2). 
FETUIN A AS AN EARLY MARKER OF DIABETIC NEPHROPATHY IN... 789

Table (2): Laboratory data for 30 healthy control subjects (group I), 30 diabetic patients without MA (group II) and 30 diabetic patients with MA (group III)

\begin{tabular}{|c|c|c|c|c|}
\hline \multirow{2}{*}{ Parameters } & $\begin{array}{l}\text { Group I } \\
\text { (Control) }\end{array}$ & $\begin{array}{c}\text { Group II } \\
\text { (Diabetics } \\
\text { without MA*) }\end{array}$ & $\begin{array}{c}\text { Group III } \\
\text { (Diabetics with } \\
\text { MA*) }\end{array}$ & \multirow[t]{2}{*}{$\begin{array}{c}\mathrm{p}^{-} \\
\text {value*** }\end{array}$} \\
\hline & Mean+SD & Mean+SD & Mean+SD & \\
\hline $\begin{array}{l}\text { Fasting blood sugar } \\
\mathrm{mg} / \mathrm{dl}\end{array}$ & $92.73 \pm 4.4$ & $205.5 \pm 92.8$ & $198.3 \pm 80.5$ & $<0.01$ \\
\hline $\begin{array}{l}\text { 2hPostprandial blood } \\
\text { sugar mg/dl }\end{array}$ & $114.9 \pm 7.66$ & $256.9 \pm 109.8$ & $262.2 \pm 86$ & $<0.01$ \\
\hline HbA1C \%** & $5.023 \pm 0.39$ & $9.46 \pm 1.09$ & $9.77 \pm 0.966$ & $<0.01$ \\
\hline Blood urea $\mathrm{mg} / \mathrm{dl}$ & $35.4 \pm 8.4$ & $34.3 \pm 8.6$ & $32.33 \pm 12.7$ & 0.412 \\
\hline Serum Creatinine $\mathrm{mg} / \mathrm{dl}$ & $0.72+0.22$ & $0.73+0.21$ & $0.71 \pm 0.25$ & 1.00 \\
\hline $\begin{array}{l}\text { Albumin/Creatinine ratio } \\
\mathrm{mg} / \mathrm{mmol}\end{array}$ & $13.27 \pm 93.7$ & $14.47+5.10$ & $205.3 \pm 93.7$ & $<0.01$ \\
\hline $\begin{array}{l}\text { Creatinine } \\
\text { Clearance.ml/min }\end{array}$ & $106.2 \pm 13.29$ & $106.2 \pm 13.3$ & $108.3 \pm 29.67$ & 0.922 \\
\hline Total .Cholesterol mg/dl & $178.54 \underline{25.11}$ & $218.09 \pm 18.84$ & $204.41+24.17$ & $<0.01$ \\
\hline Triglycerides mg/dl & $123.76 \pm 40.56$ & $126.64 \pm 28.8$ & $111.63 \pm 32.29$ & 0.205 \\
\hline LDL mg/dl & $110.27 \pm 25.15$ & $118.27 \pm 3.85$ & $122.27 \pm 24.17$ & 0.107 \\
\hline HDL mg/dl & $50.12 \pm 11.55$ & $55.53+8.16$ & $50.3 \pm 10.24$ & 0.092 \\
\hline Serum Calcium mg/dl & $9.37 \pm 0.57$ & $9.23 \pm 0.54$ & $9.29 \pm 0.57$ & 0.635 \\
\hline Serum Fetuin A ug/dl & $289.78 \pm 2.92$ & $412.91 \pm 39.78$ & $240.27 \pm 27.38$ & $<0.01$ \\
\hline
\end{tabular}

* MA: microalbuminuria, **HbA1C: glycosylated hemoglobin, ***Kruskal wallis

On comparing both group II diabetics without MA and group III diabetics with MA as regard laboratory parameters including fasting blood sugar $\mathrm{mg} / \mathrm{dl}$, two hours postprandial blood sugar $\mathrm{mg} / \mathrm{dl}$, $\mathrm{HbA} 1 \mathrm{C} \%$, blood urea $\mathrm{mg} / \mathrm{dl}$, serum creatinine $\mathrm{mg} / \mathrm{dl}$, albumin/creatinine ratio $\mathrm{mg} / \mathrm{mmol}$, creatinine clearance $\mathrm{ml} / \mathrm{min}$, Total Cholesterol mg/dl, Triglycerides $\mathrm{mg} / \mathrm{dl}$, LDL mg/dl, HDL mg/dl, Serum Calcium mg/dl, Serum Fetuin A ug/dl. There was a highly significant increase in mean $( \pm \mathrm{SD})$ of albumin /creatinine ratio in group II diabetics without MA (14.47 \pm $5.10 \mathrm{ug} / \mathrm{dl}$ ) compared to group II diabetics with MA $(205.3 \pm 93.69 \mathrm{ug} / \mathrm{dl})$ and $P$ value was $<0.01$, and highly significant decrease in serum fetuin A in group II diabetics without MA (412.91 $\pm 39.78 \mathrm{ug} / \mathrm{dl})$ compared to group II diabetics with MA $(240.27 \pm 27.38 \mathrm{ug} / \mathrm{dl})$ and $\mathrm{P}$ value was $<0.01$. There was insignificant difference in fasting blood sugar, two hours postprandial blood sugar, HbA1C, blood urea, serum creatinine, creatinine clearance, total cholesterol, triglycerides, LDL, HDL and serum calcium and pvalue was $>0.05$ between group II diabetics without MA and group III diabetics with MA (Table 3). 
NOURA A. MITKEES et al.,

Table (3): laboratory data for 30 diabetic patients without MA* (Group II) compared with diabetic patients with MA* (Group III)

\begin{tabular}{|c|c|c|c|}
\hline Groups & $\begin{array}{c}\text { Group II } \\
\text { (Diabetics without } \\
\text { MA*) }\end{array}$ & $\begin{array}{c}\text { Group III } \\
\text { (Diabetics with } \\
\text { MA*) }\end{array}$ & $\begin{array}{c}\mathrm{p}^{-} \\
\text {value** }\end{array}$ \\
\hline Parameters & Mean+SD & Mean \pm SD & \\
\hline $\begin{array}{l}\text { Fasting blood sugar } \\
\mathrm{mg} / \mathrm{dl}\end{array}$ & $205.53 \pm 92.78$ & $198.33 \pm 80.45$ & 0.794 \\
\hline $\begin{array}{l}\text { 2hPostprandial blood } \\
\text { sugar } \mathrm{mg} / \mathrm{dl}\end{array}$ & $256.97 \pm 109.87$ & $262.2 \pm 86.08$ & 0.902 \\
\hline $\mathrm{HbA1C} \%$ & $9.46 \pm 1.1$ & $9.77 \pm 0.97$ & 0.312 \\
\hline Blood urea mg/dl & $35.4 \pm 8.41$ & $32.33 \pm 12.74$ & 0.294 \\
\hline $\begin{array}{l}\text { Serum Creatinine } \\
\mathrm{mg} / \mathrm{dl}\end{array}$ & $0.72 \pm 0.22$ & $0.72 \pm 0.25$ & 1.000 \\
\hline $\begin{array}{l}\text { Albumin/creatinine } \\
\text { ratio } \mathrm{mg} / \mathrm{mmol}\end{array}$ & $14.47 \pm 5.10$ & $205.3 \pm 93.69$ & $<0.001$ \\
\hline $\begin{array}{l}\text { Creatinine Clearance } \\
\mathrm{ml} / \mathrm{min}\end{array}$ & $106.23 \pm 13.29$ & $108.27 \pm 29.68$ & 0.728 \\
\hline $\begin{array}{ll}\text { Total } & \text {.cholesterol } \\
\mathrm{mg} / \mathrm{dl} & \\
\end{array}$ & $218.0867 \pm 18.84$ & $204.41 \pm 24.17$ & 0.106 \\
\hline Triglycerides mg/dl & $126.64 \pm 28.8$ & $111.63+32.29$ & 0.293 \\
\hline $\mathrm{LDL} \mathrm{mg} / \mathrm{dl}$ & $118.27 \pm 3.85$ & $122.27 \pm 24.17$ & 1.000 \\
\hline HDL mg/dl & $55.53 \pm 8.16$ & $50.3 \pm 10.24$ & 0.184 \\
\hline $\begin{array}{ll}\text { Serum } & \text { Calcium } \\
\mathrm{mg} / \mathrm{dl} & \\
\end{array}$ & $9.23 \pm 0.54$ & $9.29 \pm 0.57$ & 1.000 \\
\hline Serum Fetuin A ug/dl & $412.91 \pm 39.78$ & $240.27 \pm 27.38$ & $<0.01$ \\
\hline
\end{tabular}

*MA: microalbuminuria, **mann-whitney U test

Correlation study was done between serum fetuin A and blood Urea $\mathrm{mg} / \mathrm{dl}$, serum creatinine $\mathrm{mg} / \mathrm{dl}$, albumin/creatinine ratio $\mathrm{mg} / \mathrm{mmol}$,creatinine clearance. $\mathrm{ml} / \mathrm{min}$, Serum Calcium $\mathrm{mg} / \mathrm{dl}$ in group I diabetic patients without MA, showed that there was significant negative correlation with albumin /creatinine ratio, (r-value $=-0.771$, $\mathrm{P}$-value < 0.05), while no significant correlation between serum fetuin $\mathrm{A}$ and blood urea, serum creatinine, creatinine clearance and serum calcium, and P-value was >0.05 (Table 4).
There was significant positive correlation between serum fetuin $\mathrm{A}$ and duration of diabetes mellitus ( $\mathrm{r}$-value $=$ 0.688 , and P-value <0.01).

There was a highly significant negative correlation in group III diabetic patients with microalbuminuria between serum Fetuin A and Albumin /creatinine ratio, (rvalue $=-0.66, \mathrm{P}$-value $<0.001)$. However, the correlation between serum fetuin A, blood urea, serum creatinine, creatinine clearance and serum calcium was insignificant. There was no significant correlation between serum fetuin $\mathrm{A}$ and duration of DM (Table 4). 
Table (4) Correlation between serum fetuin A and Blood Urea mg/dl, serum creatinine $\mathrm{mg} / \mathrm{dl}$, albumin/creati ine ratio $\mathrm{mg} / \mathrm{mmol}$, creatinine clearance.ml/min, serum calcium $\mathrm{n} \mathrm{mg/dl}$. group II diabetic patients without microalbuminuria and group III diabetic patients with microalbuminuria

\begin{tabular}{|l|c|c|c|c|}
\hline \multirow{2}{*}{ Parameters } & \multicolumn{2}{c|}{$\begin{array}{c}\text { Group II (patients } \\
\text { without MA) }\end{array}$} & \multicolumn{2}{c|}{$\begin{array}{c}\text { Group III (patients } \\
\text { with MA) }\end{array}$} \\
\cline { 2 - 5 } & r value & P value & r value & P value \\
\hline Blood Urea (mg/dl) & -0.203 & $>0.05$ & -0.027 & $>0.05$ \\
\hline Serum Creatinine (mg/dl) & -0.012 & $>0.05$ & 0.149 & $>0.05$ \\
\hline $\begin{array}{l}\text { Albumin/creatinine ratio } \\
\text { (mg/mmol) }\end{array}$ & -0.771 & $<0.05$ & -0.66 & $<0.01$ \\
\hline Creatinine Clearance (ml/min) & -0.075 & $>0.05$ & -0.347 & $>0.05$ \\
\hline Serum Calcium (mg/dl) & -0.387 & $>0.05$ & -0.078 & $>0.05$ \\
\hline Duration of D.M (years) & 0.688 & $<0.01$ & 0.282 & $>0.05$ \\
\hline
\end{tabular}

Receiver operating characteristics (ROC) curve was used to define the best cut off value of serum fetuin A which was $>294.2$, ug/dl with sensitivity of $93.3 \%$,

\section{DISCUSSION}

Diabetic kidney disease is a complication that occurs in $20-40 \%$ of all diabetic patients. In the Western world, diabetic nephropathy is the primary cause of end-stage renal disease. Both type 1 and type 2 diabetes can lead to nephropathy, but, in type 2 diabetes, a smaller proportion of patient's progress to ESRD. Because of the higher prevalence of type 2 diabetes, these patients represent more than half of diabetic patients on dialysis (De Boer et al., 2011).

It is important to emphasize that the early identification and treatment of this chronic complication which would reduce the medical and economic burden associated with it (Couser et al., 2011).

Diagnostic and prognostic markers to predict diabetic nephropathies at early stages are important as early intervention can slow down deterioration of kidney function and improve patient outcomes. specificity of $93 \%$, positive predictive value of $92.7 \%$, negative predictive value of $93.8 \%$ with diagnostic accuracy of $91.6 \%$.

Fetuin-A was originally discovered to be an inhibitor of vascular calcification. Fetuin-A has been demonstrated to play an important role in free fatty acid induced insulin resistance at liver. Increased fetuin-A in patients with prediabetes is associated with increased progression to diabetes and decreased reversal to normoglycemia and is also used as a predictor of adverse glycemic outcomes in pre-diabetes (Dutta et al., 2014).

Being more sensitive as a marker for early detection of diabetic nephropathy than other kidney function tests such as creatinine, microalbiminuria and eGFR and as a prognostic tests for follow up, our research was to assess fetuin A level between clinically normal persons, diabetics without microalbuminuria and diabetics with microalbuminuria which reveals early kidney affection being a beneficial, accurate, less invasive method 
of early detection of diabetic nephropathy in type 2 diabetics.

The results of our study revealed that there was no significant difference between diabetic patients with or without nephropathy as regard age, sex. Which was previously reported by Ramadan and his Colleagues (2011).

In the presented study serum fetuin A was significantly increased in diabetic patients without MA compared to control group. Also, it significantly increased in control group compared to the diabetic patients with microalbumunuria. This could be due protective effect of fetuin A of vascular complications in healthy control group compared to the diabetic patients. Al-Said and his Colleagues (2018) also found that there was a highly significant increase in the mean levels of fetuin $\mathrm{A}$, in the diabetic patients with diabetic nephropathy, retinopathy and microvascular complications compared to healthy control group.

However, El-Batch and her Colleagues (2015) found a significant increase in serum fetuin A levels in microalbuminuric patients compared to normoalbuminuric patients and to control group. Those authors explained these results by the the role of fetuin-A in mediating insulin resistance, lipid profile abnormalities and endothelial dysfunction which underlie the association between fetuin-A and abnormal albuminuria, Budoff and his Colleagues (2011) found that serum levels of fetuin-A were significantly higher among Latinos with DN when compared to either African Americans with DN or Latino diabetics with normoalbuminuria when assessing the role of fetuin-A in the coronary artery calcification burden seen in non-dialyzed individuals with diabetic nephropathy. Ramadan and his Colleagues (2011) found that there was a significant reduction in serum fetuin $\mathrm{A}$ levels in controlled and uncontrolled diabetic patients compared to control group. A significant decrease was also detected in uncontrolled diabetic patients when compared to controlled diabetic patients. Other authors reported that serum fetuin-A is lower in microalbuminuria patients compared with normo- and macroalbuminuric patients (Koluman et al., 2013).

In the presented study; ROC curve was used to define the best cut off value of serum fetuin A which was $>294.2 \mathrm{ug} / \mathrm{dl}$ with sensitivity of $93.3 \%$, specificity of $93 \%$, positive predictive value of $92.7 \%$, negative predictive value of $93.8 \%$ with diagnostic accuracy of $91.6 \%$. Howerver El-Batch and her Colleagues (2015) found that fetuin-A cutoff value was $>26.5 \mathrm{mg} \%$, they found that fetuin A had the highest sensitivity, negative predictive value and accuracy for detecting microalbuminuria.

\section{CONCLUSION}

The serum fetuin $A$ is higher in patients with type 2 diabetes mellitus without microalbuminuria compared to those with microalbuminuria. Also there was negative significant correlation between serum fetuin $\mathrm{A}$ and albumin/ creatinine ratio in both groups; this means that high serum fetuin A level may have protective effect against development of diabetic nephropathy. This could be used as early diagnostic marker before development of microalbuminuria in diabetic nephropathy. 


\section{REFERENCES}

1. Afkarian M, Zelnick LR, Hall YN, Heagerty PJ, Tuttle K, Weiss NS and De Boer IH (2016): Clinical manifestations of kidney disease among US adults with diabetes, 1988-2014. JAMA 316:602-610.

2. Al-Said NH, Taha FM, Abdel-Aziz GM and Abdel-Tawab MS. (2018): Fetuin-A level in type 2 diabetic patients: relation to microvascular complications. Egypt J Intern Med., 30:121-30.

3. Bjornstad P, Cherney D and Maahs DM. (2014): Early diabetic nephropathy in type 1 diabetes: new insights. Curr Opin Endocrinol Diabetes Obes., 21 (4):279-86.

4. Budoff MJ, Rader DJ, Reilly MP, and Feldman HI (2011): Relationship of estimated GFR and coronary artery calcification in the CRIC (Chronic Renal Insufficiency Cohort) Study. Am J Kidney Dis., 58(4):519-526.

5. Calcutt N. A., Cooper M. E., Kern T. S. and Schmidt A. M. (2009): Therapies for hyperglycemia-induced diabetic complications: from animal models to clinical trials. Nat. Rev. Drug Discov., 8: 417-429.

6. Couser W. G., Remuzzi G., Mendis S. and Tonelli M. (2011): The contribution of chronic kidney disease to the global burden of major non communicable diseases. Kidney Int., 80: 1258-1270.

7. De Boer IH, Rue TC, Hall YN, Heagerty PJ, Weiss NS and Himmelfarb J. (2011): Temporal trends in the prevalence of diabetic kidney disease in the United States. JAMA, 305:2532-2539.

8. Dutta D, Mondal SA, Kumar M and Reja AH (2014): Serum fetuin-A concentration predicts glycaemic outcomes in people with prediabetes: A prospective study from Eastern India le with prediabetes: A prospective study from Eastern India, Diabetic Medicine 31: 1594-9.

9. El-Batch M, Hamouda HE, Hassan SA, Mohamed WF and El-Horany HE. (2015): Preliminary study of biochemical role of serum fetuin-a level and its gene polymorphism in diabetic patients with microalbuminuria. Journal of Diabetes, Metabolic Disorders \& Control, 5:158-164.

10. Forbes JM and Cooper ME. (2013): Mechanisms of diabetic complications. Physiol Rev Suppl, 93: 137-88.

11. Hasan MJ, Muqueet A, Sharmeen A and Hoque MR. (2015): Prevalence of microalbuminuria in relation to glycemic control in type-2 diabetic patients in Mymensingh. Mymensingh Med J., 24 (1): 18-24.

12. Koluman BU, Mutluay R, Derici UB, Arinsoy T, Senlik Z, Bahar B, Sancak B, Oktan SO and Sindel S (2013): Association between osteoprotegerin, fetuin-A, carotid intima media thickness, and urinary albumin excretion in Type 2 diabetes. Clinical Nephropathy, 80 (1):9-1.

13. Persson F and Rossing P. (2018): Diagnosis of diabetic kidney disease: state of the art and future perspective. Kidney Int Suppl., 8 (1):2-7.

14. Ramadan A, Shoukry $A$ and Ismail $M$ and Boraiet M (2011): Serum Fetuin-A Levels in Type 2 Diabetes Patients with Early Diabetic Nephropathy: It's Relation to Diabetes Control. Journal of American Science, 7 (5): 759-765. 
فيتوين أ كدلاله للتشخيص المبكر لاعتلال الكلى في مرضى النى

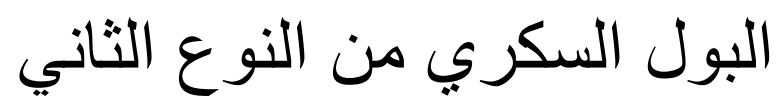

نورا عبد العزيز ميتكيس، هلى محمد السيد، عديله محمود جاد، هيام حمزه منصور،

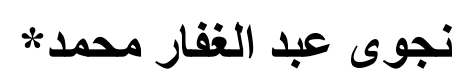

قسمي الباطنة العامة كلية الطب (بنات) جامعة الازهر وقسم الباثولوجيا الاكلينيكية و الكيميائية

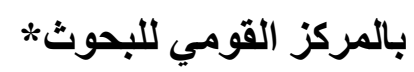

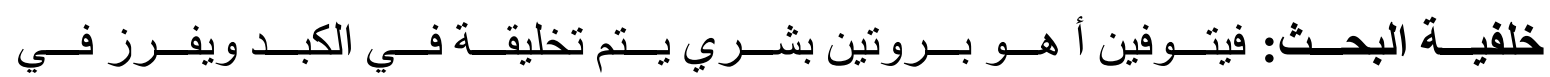

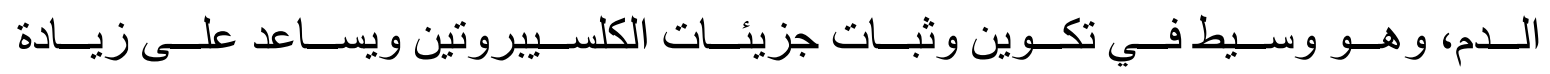

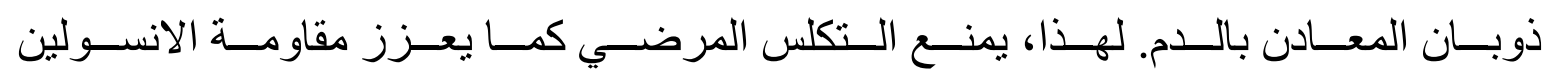
بالجسم.

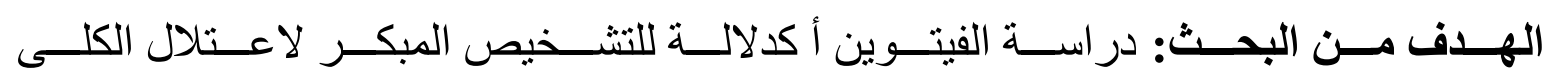
في مرضى البول السكرى من النوع الثاني.

المرضـى و طــرق البحــث: يثـــمل هــذا البحــث تسـعون شـــص مقسـمين الـى ثــلاث

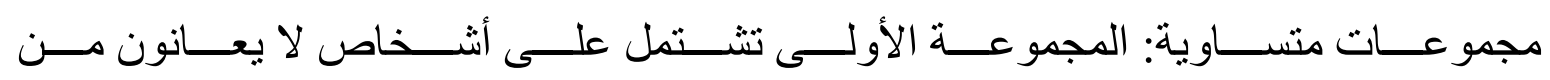

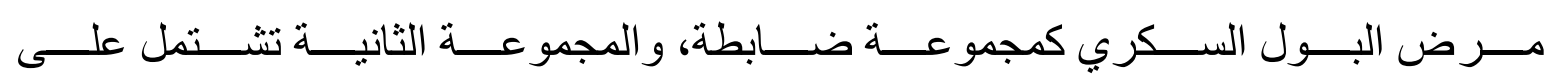

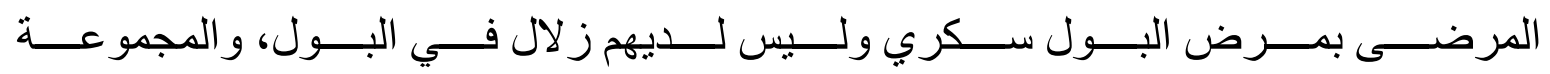

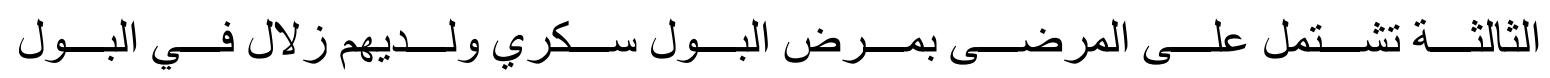

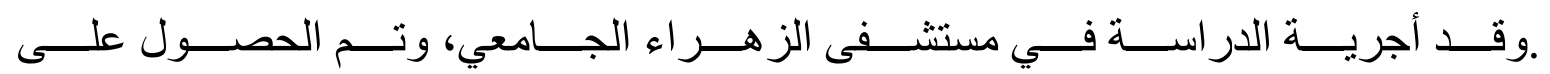

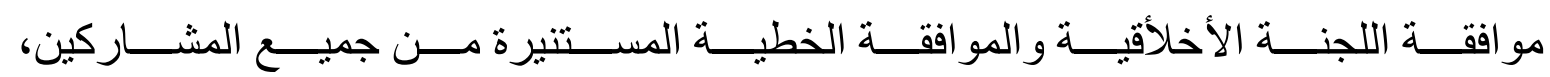
وقد تحقق اختيار المرضى من خلال عدد من معايير الاشتمال و الاستبعاد.

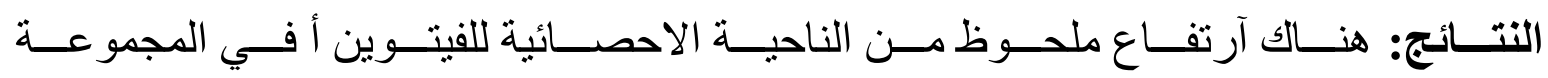

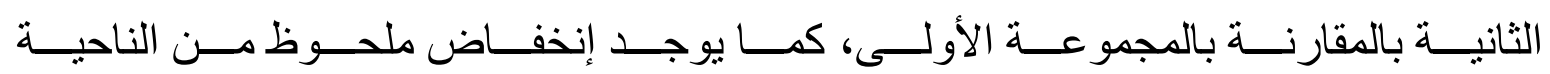

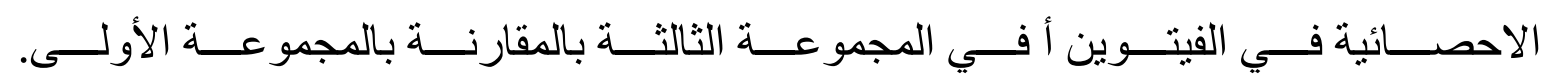

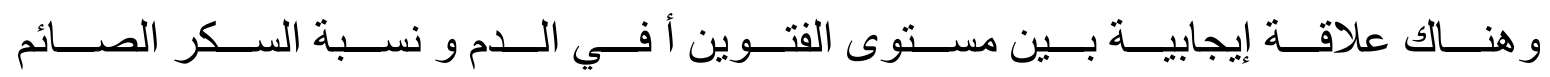

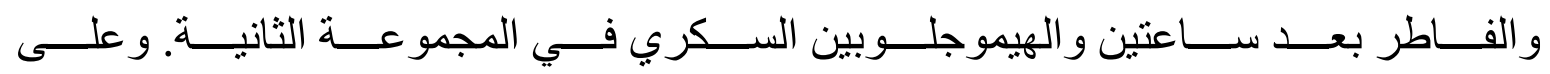


FETUIN A AS AN EARLY MARKER OF DIABETIC NEPHROPATHY IN... 795

النقــيض، يوجـــد علاقــة ســلبية بــين مســتوى الفتـــوين أ فـــي الـــدم ونســبة الســكر

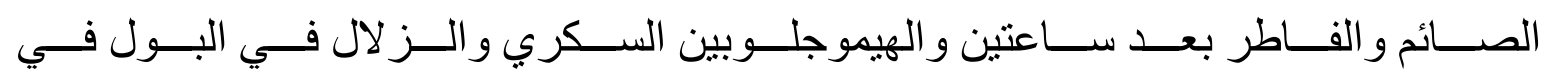
المجمو عة الثالثة.

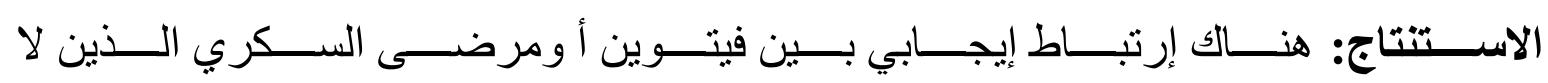

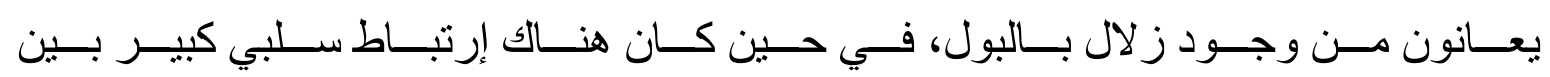

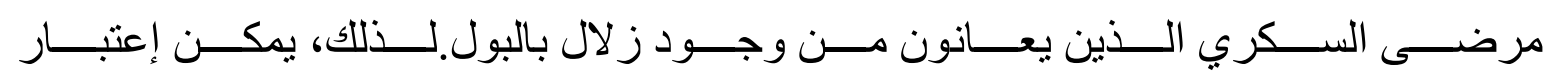
فيتوبن أ علامة مبكرة لاعتلال الكلية السكري. 